\title{
Nomas jeb īres līguma piemērošana darba tiesisko attiecību reglamentēšanai jeb romiešu darbu īres līgums un romiešu darbuzṇēmuma līgums
}

\author{
Allars Apsītis, Dace Tarasova \\ Rīgas Stradiña universitāte, Latvija \\ allars@inbox.lv
}

\section{Kopsavilkums}

Rakstā atspoguḷots autoru pētijums par juridiskajām konstrukcijām romiešu tiesību pirmavotos saistībā ar brīvu personu (ne vergu) nodarbināšanu par atlīdzību, pusēm savstarpēji vienojoties. Šìs juridiskās konstrukcijas tika būvētas uz nomas jeb īres līguma (locatio conductio ${ }^{1}$ ) tiesiskās bāzes ar darbu īres jeb darba līguma (locatio conductio operarum) un darbuzṇēmuma līguma (locatio conductio operis) palīdzību. Darbu îres jeb darba līgums bija citas personas darba jeb sniegto pakalpojumu îrēšana, kur darbinieks kā savu darbu (operae) izīrētājs (locator) sniedza pakalpojumus darba devējam kā îrniekam (conductor) atbilstīgi tam, kā puses bija savstarpēji vienojušās. Darbiniekam jeb izīrētājam pienācās atbilstīga samaksa jeb darba alga (merces).

Darbuznēemuma līgums (locatio conductio operis (faciendi)) bija tāds līgums, saskaṇā ar kuru uzṇēmējs kā īrnieks (conductor, redemptor operis) uzṇēmās pienākumu veikt pakalpojumus vai darbus (opus) no izīrētāja jeb pasūtītāja piegādātā materiāla vai ar izīrētāja jeb pasūtītāja piegādāto materiālu par savstarpēji norunātu samaksu.

Rakstā apskatìts un analizēts avotos rodamais līgumslēdzēju pušu tiesību un pienākumu, līgumu darbības termiṇu, pakalpojumu cenu veidošanas, darbu pieṇemšanas, maksāšanas noteikumu, pušu atbildības, aizskarto interešu aizsardzības mehānismu u.c. regulējums. Iepriekšminēto līgumu tiesiskā reglamentācija atzīstama par savam laikam pietiekami efektīvu, visai detalizētu un komplicētu legālo aparātu Romas pilsoṇu mantisko interešu aizsardzībai.

\footnotetext{
1 Šeit un turpmāk rakstā teksts svešvalodā, kas slīpināts, ir latīṇu valodā.
} 
Allars Apsītis, Dace Tarasova. Nomas jeb īres līguma piemērošana darba tiesisko attiecību reglamentēšanai jeb romiešu darbu īres līgums un romiešu darbuzñēmuma līgums

Atslēgvārdi: romiešu tiesības, darbu īre, darbu īres jeb darba līgums (locatio conductio operarum), darbuzñēmums, darbuzṇēmuma līgums (locatio conductio operis).

\section{levads}

Pētījums tapis kā atsevišḳa daḷa no autoru realizētās romiešu tiesību pirmavotu izpētes jautājumā par romiešu juridisko principu ietekmi uz moderno, īpaši Latvijas Republikas tiesībās ietverto, tiesisko institūtu attīstību. Saskaņā ar autoru rīcībā esošo informāciju Latvijas pētnieki minēto tematiku no šãda skatupunkta ir visai maz aplūkojuši, tāpēc šis pētījums varētu dot ieguldījumu nacionālās tiesību zinātnes attīstībā.

Šì darba mērksis bija izpētìt un izanalizēt romiešu tiesību pirmavotos rodamo informāciju par romiešu darbu īres jeb darba līguma un darbuzṇēmuma līguma tiesiskās reglamentācijas īpatnībām.

Pētījuma gaitā realizēta romiešu tiesību pirmavotu (Codex Iustinianus, C 4.65. tit.; Digesta, D 19.2. tit.; Iustiniani Institutiones, I 3.24. tit.) izpēte un analīze, izmantojot induktīvo, deduktīvo un salīdzinošo metodi.

\section{Rezultāti un diskusija}

Saskaṇā ar romiešu tiesību principiem juridiskās konstrukcijas brīvu personu (ne vergu) nodarbināšanai par atlīdzību, pusēm savstarpēji vienojoties, tika būvētas uz nomas jeb īres līguma (locatio conductio) tiesiskās bāzes:

"Kad vien [iz]darīšanai kaut kas [uz]dots, [tā] noma jeb īre ir" (quotiens autem faciendum aliquid datur, locatio est) (D 19.2.22.1) [4, 287];

"Ja kāds izīrē [iz]darīt, ko es īrēju..." (si cui locaverim faciendum quod ego conduxeram...)

(D 19.2.48. pr.) [4, 289].

Minētais attiecināms galvenokārt uz meistaru, amatnieku un strādnieku veikto darbu, turpretī intelektuālo profesiju pārstāvju (ārstu², juristu ${ }^{3}$, zemes mērnieku, skolotāju, arhitektu u. c.) sniegtie pakalpojumi, t. s. operae liberalis, saskaņā ar klasiskajām romiešu tiesībām nevarēja būt nomas jeb īres līguma (locatio conductio) objekts, kaut arī principāta laikā kompensācija par šāda veida profesionālajiem pakalpojumiem varēja tikt iegūta ārkārtas (ekstraordinārā) procesa kārtībā (sk., piemēram, D 19.2.38.1) [4, 289]. Tādējādi

2 Par romiešu mediḳa legālā statusa īpatnībām sk.: Apsitis, A. The reimbursement for the medical treatment expenses within the framework of Roman Partnership Agreement (societa). SHS WEB Conferences, 2014; 1000003 (2014), 1-6. Pieejams: http://dx.doi.org/10.1051/shsconf/20141000003 [sk. 10.09.2017.].

3 Jāpiebilst, ka arī nomas jeb īres līgumu (locatio conductio) reglamentējošos digestu (Digesta) fragmentos (D 19.2. tit.) rodams nosacījums, ka advokātiem, ja vien par tiem nevar apgalvot, ka viṇi nav tiesas lietā darbojušies, honorāru atpakal atmaksāt nevajadzētu - klients samaksāto advokāta honorāru atpakal prasīt nevar (sk. D 19.2.38.1; 4, 289]. 
Allars Apsittis, Dace Tarasova. Nomas jeb īres līguma piemērošana darba tiesisko attiecību reglamentēšanai jeb romiešu darbu īres līgums un romiešu darbuzṇēmuma līgums

manuālo darbu veikšanas tiesiskajam nodrošinājumam tika izmantoti galvenokārt divi uz nomas jeb ìres līguma bāzes veidoti līgumi: locatio conductio operarum - darbu ìres jeb darba līgums - un locatio conductio operis (faciendi) - darbuznēmuma līgums.

Darbu ire, par ko tika noslēgts darba līgums (locatio conductio operarum), bija citas personas darba jeb sniegto pakalpojumu îrěšana - darbinieks kā savu darbu (operae) izīrētājs (locator) sniedza pakalpojumus darba devējam kā īrniekam (conductor) atbilstīgi tam, kā puses bija savstarpēji vienojušās. Darbiniekam pienācās atbilstīga samaksa jeb darba alga (merces):

"Kas savu darbu izīrējis (qui operas suas locavit), [tam par] visu [nolīgto jeb nostrādāto] laiku vajadzētu saṇemt atlīdzību (mercedem)..." (D 19.2.38. pr.) [4, 289]

Romiešu tiesību pirmavotos šì līguma sakarā minēts, piemēram, protokolists jeb rakstvedis (exceptor) ${ }^{4}$, kurš izīrējis savus pakalpojumus jeb darbu (operas suas locasset); viṇa līgumattiecības ar valsti vai pašvaldību saglabājas, kaut arī tas ierēdnis, kas viṇa pakalpojumus īrējis (conduxerat), ir nomiris - ja vien gada (anno) laikā nav saṇemta atlīdzība (mercedes) no kāda cita (D 19.2.19.9) [4, 287]. Lìdzīgi imperatora Cēzara legāta (legato Caesaris) ${ }^{5}$ nāves gadījumā alga (salarium) viṇa pavadoṇiem bija samaksājama par visu atrunāto atlikušo kalpošanas laiku, paredzot, ka minētie pavadoṇi (comites) šajā laikā nebūs citu nodarbināti (D 19.2.19.10) [4, 287].

Darbinieks jeb izīrētājs varēja savus pakalpojumus izīrēt, piemēram, uz kādu darba devēja jeb īrnieka un darbinieka jeb izīrētāja savstarpēji atrunātu laika periodu ([..] temporis certi suas [..] locaverint operas) (C 4.65.22) [3, 190]. Ja darbu īres līgumā (locatio conductio operarum) bija noteikts konkrēts darba izpildes termin,š, bet darbs termin̄ā netika izpildīts, īrniekam jeb darba devējam bija pienākums samaksāt izīrētājam jeb darbiniekam (locatoris) atbilstīgi atrunātajā termiñā padarītajam, pieņemot, ka saistība noslēgta par tādu darba apjomu, kādu labs vīrs (vir bonus, vidējs romiešu darbinieks) noteiktajā termiṇā tiešām var paveikt, un ka pušu nolūks bijis panākt darbu pabeigšanu tieši atrunātajā termiṇā (D 19.2.58.1) [4, 290].

Tika norādìts - samaksas apjoms neapmierina, nav iespējams apstrīdēt līguma spēkā esamību, uzdodot par ieganstu mazu nomas maksu (praetextu minoris pensionis); izīrēšana jeb iznomāšana vienalga notika - bija spēkā (locatione facta), ja nevarēja pierādìt nekādu oponenta viltu (si nullus dolus adversarii probari possit), tāpēc nomu jeb īri nevarēja anulēt (rescindi locatio non potest) (D 19.2.23) [4, 287].

4 Exceptor - rakstvedis, zemākā līmeṇa ierēdnis, protokolu, ierakstu pārrakstītājs, rakstvedis tiesā, senātā, kas fiksēja arī notikumu hronometrāžu, pulksteṇa laiku [2, 461]. Provinču tiesnešiem šādi "piekomandētie" rakstveži nesaṇēma algu no valsts kases (taču viṇiem tika garantēta aizsardzība no uzmākšanās draudiem pienākumu pildīšanas laikā, izpildot municipāla līmeṇa pienākumus viṇu pilsētās (sk. C 12.49.5)) [3, 479].

${ }^{5}$ Legati Augusti (Caesaris) - imperatora sūtṇi speciālās misijās. Legati Augusti (Caesaris) pro praetore - imperatora provinču pārvaldnieki jeb pilnvarotie uz nenoteiktu laiku [2, 539]. 
Allars Apsittis, Dace Tarasova. Nomas jeb īres līguma piemērošana darba tiesisko attiecību reglamentēšanai jeb romiešu darbu īres līgums un romiešu darbuzṇēmuma līgums

Līgums, līdzīgi kā jebkurš cits kontrakts vai pakts, bija uzskatāms par spēkā neesošu, ja tā nosacỉjumi bija pretrunā ar labiem tikumiem ${ }^{6}$ (contra bonos mores) (C 8.38.4 [3, 351], C 2.3.6 [3, 93], D 45.1.61 [4, 774], D 50.17.116. pr. [4, 923] u.c.).

Ja kāds izīrētājs jeb darbinieks izīrēja savus pakalpojumus diviem īrniekiem jeb darba devējiem, viṇam bija pienākums strādāt tā labā, kurš hronolog̣iski pirmais (priori conductori) bija noslēdzis ar vinuu līgumu (D 19.2.26) [4, 287].

Darba devējam jeb ìrniekam piekrita tiesības tiesas ceḷā pieprasìt no darbinieka jeb izīrētāja, lai tas izpildītu pienākumus, kurus bija uzṇēmies:

“[..] piekrīt par nomu jeb īri prasījums ([..] habere ex locato actionem)” (D 19.2.48. pr.) [4, 289], "[..] lietu izmeklējis kompetents tiesnesis liks ievērot vienošanos ([..] causa cognita competens iudex conventionem servari iubebit)." (C 4.65.22) [3, 190]

Avotos rodamas normas, kas vērstas pret darba devēju jeb ìrnieku patvalı un vardarbību pret saviem darbiniekiem jeb darbu izīrētājiem. Norādīts, piemēram, uz kurpniekmeistara tiesībām piemērot mērenus ietekmēšanas līdzekḷus pret savu mācekli:
"[..] kaut gan skolotājiem / meistariem ir piešķirtas viegla soda [pielietošanas tiesības] (quamvis enim magistris levis castigatio concessa sit)", tomēr gadījumā, kad kurpnieks, sitot savu mācekli ar kurpes liesti, traumējis zēna aci (“[..] ja kurpnieka zēns, kas nepie- tiekami labi strādājis, ar kurpes liesti tik mežonīgi sists pa kaklu (si sutor puero parum bene facienti forma calcei tam vehementer cervicem percusserit) tā, ka acs iztecējusi (ut ei oculus effunderetur), no nomas līguma viṇa tēvam piekrīt tiesības celt prasījumu (ex locato esse actionem patri eius)." (D 19.2.13.4) [4, 285]

Darbuzṇēmuma līgums (locatio conductio operis (faciendi)) bija līgums, saskaṇā ar kuru uzṇēmējs kā īrnieks (conductor, redemptor operis) uzṇēmās pienākumu veikt pakalpojumus vai darbus (opus) no izīrētāja jeb pasūtīāja (locator) piegādātā materiāla vai ar viña materiālu par savstarpēji norunātu samaksu (merces). Avotos rodama informācija, ka tas noticis, piemēram, par dārgakmeṇu apstrādi ("ja dārgakmens ir dots ietveršanai vai iegravēšanai [meistaram] (si gemma includenda aut insculpenda data sit)") (D 19.2.13.5) [4, 285], drēbju tīrišsanas pakalpojumiem ("ja vēlējs / balinātājs drēbes spodrināšanai pieñēmis (si fullo vestimenta polienda acceperit)") (D 19.2.13.6) [4, 285], sk. arī D 19.2.25.8 [4, 287], D 19.2.60.2 [4, 290], I 3.24.1 [5, 40]), drēbnieka pakalpojumiem (“ja [..] labotājam / drēbniekam labošanai drēbes [..] dod (si [..] sarcinatori sarcienda vestimenta [..] dederit)") (I 3. 24.1) [5, 40], sk. arī D 19.2.25.8 [4, 287]), aizgādnību pār lietām pret samaksu (D 19.2.40) [4, 289], zeltkal,a pakalpojumiem ([..] kad [ar] zeltkali Ticijs vienojies ([... cum aurifice Titio convenerit)) (I 3.24.4) [5, 40], starpniecību kviešu un miežu iepirkšanā publiskām vajadzībām (C 4.65.14) [3, 189] u.c.

6 Jāpiebilst, ka romiešu jēdziens “labi tikumi” (boni mores) un tam atbilstīgā idejiskā nozīme pārṇemta mūsdienu Latvijas darba tiesību tiesiskajā regulējumā (sk., piemēram, Darba likuma 101. panta pirmās dạ̦as 3. punktu) [7, 101. p.]. Sk. arī: Tarasova, D. Darba tiesisko attiecību izbeigšanas problemātika Darba likuma 101. panta pirmās daļas 3. un 4. punkta gadījumos. Socrates: RSU Juridiskās fakultātes elektroniskais juridisko zinātnisko rakstu žurnāls, 2016, 3(6), 99-107. Pieejams: https:// www.rsu.lv/sites/default/files/imce/Dokumenti/izdevumi/socrates_6_2017.pdf [sk. 10.09.2017.]. 
Allars Apsītis, Dace Tarasova. Nomas jeb īres līguma piemērošana darba tiesisko attiecību reglamentēšanai jeb romiešu darbu īres līgums un romiešu darbuzñēmuma līgums

Ja darba izgatavošanai izmantoja pašam izgatavotājam piederošu materiālu, tas bija pārdevums (emtio), nevis darbuzṇēmums (I 3.24.4) [5, 40]. Šajā sakarībā Justiniāna institūcijās (Iustiniani institutiones) ir piemērs ar problēmjautājuma iztirzājumu - kā būtu jārīkojas situācijā, kad pasūtītājs vienojas ar zeltkali par noteikta svara un noteiktas formas gredzenu izgatavošanu no zeltkalim piederoša zelta, nosakot zeltkalim atlīdzību, piemēram, desmit zelta monētu (verbi gratia aureos decem) apmērā? Vai šeit būtu apskatāms pirkuma un pārdevuma līgums vai nomas jeb īres līgums (t. i., darbuznēēmuma lïgums) ([..] utrum emptio et venditio contrahi videatur, an locatio et conductio?)? Un atbilstīgi norādīts: varētu pien,emt, ka attiecībā uz materiālu patiešām noslēgts pirkuma un pārdevuma līgums, bet attiecībā uz darbu - nomas jeb īres līgums (notikusi "iznomāšana un nomāšana" (materiae quidem emptionem venditionemque contrahi, operae autem locationem et conductionem)), tomēr nolemts, ka šādā situācijā darbojas tas, ka ir noslēgts vienīgi pirkuma un pārdevuma līgums (tantum emptionem et venditionem contrahi). Bet, ja pasūtīājs savu zeltu devis (quodsi suum aurum [..] dederit) un samaksa par darbu noteikta (mercede pro opera constituta), nav apšaubāms, ka [tā] ir noma / īre ("iznomāšana un nomāšana") (dubium non est quin locatio et conductio sit) (I 3.24.4) $[5,40]$.

Saistībā ar samaksu pušu atrunātie maksāšanas noteikumi varēja paredzēt vai nu maksāšanu par visu darbu kopumā, vai arī pa dạ̦ām - atseviški par katru paveicamā darba tehnologisko elementu:

"[..] pat ja [esat] vienojušies, ka par katru [atsevišķu] darba [elementu] dodama noteikta naudas [summa] (tametsi convenit, ut in singulas operas certa pecunia daretur))."

(D 19.2.51.1) $[4,289]$

Tādējādi līgumā atrunātā pakalpojuma cena varēja tikt attiecināta uz visu darbu apjomu kopumā vai arī sadalīta pa atsevišķām pozịcijām:

“[..] nav patiešām nekādas atškirības (non enim quicquam interest), vai viena [kopēja] cena darbam vai [arī] ir katrs darba [elements atsevišḳi] pozicionēts (utrum uno pretio opus an in singulas operas collocatur), ja vien viss beigās uz uzṇēmēju jeb irnieku attiecas (si modo universitas consummationis ad conductorem pertinuit)." (D 19.2.51.1) [4, 289]

Cenā varēja iekḷaut atsevišḳi izdalītas materiālu un darbaspēka izmaksas:

“[..] par akmeniem un roku cenu ([..] pro lapide et manupretio)." (D 19.2.30.3) [4, 288]

Tika praktizēta gabaldarba samaksa:

"Tā kā [būv]darbos būs akmens darbi (quoad in opus lapidis opus erit), [..] īpašnieks ìrniekam jeb uzṇēmējam par pēdu [katru] vienu [uzbūvēto] septinnas [naudas vienības] dos ([..] dominus redemptori in pedes singulos septem dabit)." (D 19.2.30.3) [4, 288]

Varēja maksāt arī par noliktiem laika intervāliem:

"[..] un par darbu uznēemējam jeb îrniekam katru dienu devu noteiktu samaksu (ut pro opere redemptori certam mercedem in dies singulos darem)." (D 19.2.51.1) [4, 289] 
Allars Apsittis, Dace Tarasova. Nomas jeb īres līguma piemērošana darba tiesisko attiecību reglamentēšanai jeb romiešu darbu īres līgums un romiešu darbuzṇēmuma līgums

Lai iestātos samaksas veikšanas pienākums, kā nosacỉjumu parasti atrunāja pasūtītāja jeb izīrētāja vai kādas trešās personas dotu apstiprinājumu - darbu pien̦emšanu (D 19.2.24. pr. [4, 287], D 19.2.36 [4, 289], D 19.2.37 [4, 289], D 19.2.60.3 [4, 290]). Piemēram, mājas būvdarbu veikšana bija tā izīrēta (domus facienda locata erat ita), ka izīrētājam jeb pasūtītājam vai viṇa mantiniekam vajadzēja tos vai nu pieṇemt, vai nepienemt (probatio aut improbatio locatoris aut heredis eius) (D 19.2.60.3) [4, 290]. Arī darbu specifiskais raksturs noteica pien,emšanas nepieciešamību: "[..] ja tādi darbi bijuši, ka tiem vajadzētu pārbaudīšanu / pieṇemšanu (si tale opus fuit, ut probari deberet)" (D 19.2.37) [4, 289].

Neatkarīgi no tā, vai darbus pieṇemma pats pasūtītājs jeb izīrētājs vai trešā persona, padarītā novērtējumam bija jābūt adekvātam un šāda veida darbiem objektīvi atbilstīgam - tādam, kādu analog̣iskā situācijā dotu labticīgs vidusmēra romietis, ja nomas jeb īres līgumā (darbuzṇēmuma līgumā) bija iekḷauts (si in lege locationis comprehensum sit) nosacijums, ka darbi pieņemami ar saimnieka lēmumu / spriedumu (ut arbitratu domini opus adprobetur), pien̦emšanai bija jānotiek tāpat, "[..] kā ja labs vīrs būtu pieṇēmis lēmumu / spriedumu (ac si viri boni arbitrium comprehensum fuisset)". Līdzīgi pienācās rīkoties situācijā, kad pieṇēmējs bija trešā persona:
"[..] ja cita jebkura lēmums / spriedums ir pieñemams (si alterius cuiuslibet arbitrium comprehensum sit), [..] laba ticība prasa ([..] fides bona exigit), lai šāds lēmums / sprie- dums [..] [būtu] tāds, kā labam vīram pieklātos (ut arbitrium tale [..], quale viro bono convenit)." (D 19.2.24. pr.) [4, 287]

Parasti ar darbu pieṇemšanu saprata izpildījuma novērtēšanu atbilstīgi līguma specifikācijas kvalitatīvajām prasībām, savukārt novērtēšana saistībā ar darbu izpildes termiṇiem un to ievērošanas disciplīnu notika tikai tad, ja tā bija līgumā īpaši atrunāta:

“[..] lēmums / spriedums par darbu kvalitāti (arbitrium ad qualitatem operis), nevis par prasīto laiku (non ad prorogandum tempus) [..] attiecināms (pertinet), izṇemot, [ja] tas pats ir iekḷauts līgumā (nisi id ipsum lege comprehensum sit)." (D 19.2.24. pr.) $[4,287]$

Puses varēja vienoties par darbu pieņemšanu un attiecīgo samaksu atbilstīgi kādiem izmērāmiem kritērijiem:

"[..] ir tā īrēts ([..] ita conductum sit), ka maksājams [par] pēdām vai apjomiem / izmēriem (in pedes mensurasve praestetur sit)." (D 19.2.36) [4, 289]

Darbu pieñemšana un apmaksa varēja tikt organizēta pa atsevišḳiem attiecīgā tehnologiskā procesa etapiem - atbilstīgi faktiski paveiktajam:

"Ja vien nav tā [līgumā atrunāts, ka] par katru [atsevišḳo, atsevišḳa] darbu būs noteikta samaksa / alga (nisi si ideo in operas singulas merces constituta erit) un [atseviškss] spriedums / novērtējums no saimnieka [katram atseviškị] padarītajam darbam (ut arbitrio domini opus efficeretur)." (D 19.2.51.1) [4, 289] 
Allars Apsītis, Dace Tarasova. Nomas jeb īres līguma piemērošana darba tiesisko attiecību reglamentēšanai jeb romiešu darbu īres līgums un romiešu darbuzṇēmuma līgums

Avotos rodama informācija arī par līdz galam nepabeigta tehnoloǵiskā procesa rezultātu uzskaiti un novērtēšanu:

“[..] jautājums ir (quaesitum est), vai faktiski padarīto darbu, pat nepilnīgu, nepabeigtu, nepieciešams mērīt (utrum factum opus an etiam imperfectum metiri oporteret)". Atbilde ir "jā", pat nepilnīgu un nepabeigtu (respondit etiam imperfectum)." (D 19.2.30.3) [4, 288]

Ja darbu pieṇemšana bija panākta ar apzinātu prettiesisku mānīšanos un krāpšanu jeb viltu (dolus), pien,emšanu atzina par spēkā neesošu un cietušais varēja celt attiecīgu prasījumu tiesā:

“[..] No tā izriet (quibus consequens est), ka spēkā neesoša ir pieṇemšana, ko uzṇēmējs jeb irnieks ir taisijis ar viltu (ut irrita sit adprobatio dolo conductoris facta), un var no nomas jeb īres līguma prasit (ut ex locato agi possit)." (D 19.2.24. pr.) [4, 287]

Līdz brīdim, kad darbi jāpieṇem pasūtītājam jeb izīrētājam (locator), tie atradās īrnieka jeb uzñēmēja (conductor) atbildībā, kurš uzn,ēmās risku par paveiktā darba iespējamu bojāeju:

"Darbi, kuri attiecībā uz nomas jeb ìres [līgumu veicami] ir, līdz [pat brīdim, kad tie pasūtitāja jeb izīrētāja] pieṇemti (opus quod aversione locatum est donec adprobetur), uznẹemēja jeb ìrnieka risks ir (conductoris periculum est), [ja] tā ìēts ir ([..] ita conductum sit), ka [par] pēdām vai apjomiem jeb izmēriem maksājams (in pedes mensurasve praestetur sit), tiktāl uzṇēmēja jeb îrnieka risks ir, ciktāl nomērǐšana nav notikusi (eatenus conductoris periculo est, quatenus admensum non sit)." (D 19.2.36) [4,289]

Izṇēmums bija nepārvaramas varas (vis maior) gadījumi, kad, ja vien puses nebija citādi vienojušās, cieta pasūtītājs jeb izīrētājs (locator), nevis uzṇēmējs jeb īrnieks:

"Ja, pirms pasūtītājs jeb izīrētājs darbus pieṇēmis (si, priusquam locatori opus probaretur), [tie] ir kādas [nepārvaramas] varas iznīcināti (vi aliqua consumptum est), zaudējums tādējādi attiecas uz pasūtitāju jeb izīrētāju (detrimentum ad locatorem ita pertinet)." (D 19.2.37) [4, 289]

"Ja tomēr nepārvarama vara darbus vispirms sabojājusi, [tos], kuri pienemami (si tamen vi maiore opus prius interciderit quam adprobaretur), pasūtītāja jeb izīrētāja risks ir (locatoris periculo est), izṇemot, ja pastāv citāda vienošanās (nisi si aliud actum sit)." (D 19.2.36) [4, 289]

Tādējādi uzṇēmējs jeb īrnieks neatbildēja par bojājumiem un zaudējumiem, kas radušies dabas spēku (vi naturali) ietekmē, attiecīgi saglabājot tiesības uz samaksu par padarìto:

"Marcijs [uzṇēmējs jeb îrnieks] īrēja mājas [būvdarbu] veikšanu no Flaka [pasūtîtāja jeb izīrētāja] (Marcius domum faciendam a Flacco conduxerat). Tad [situācijā, kad] darbi [tikai] daḷēji izpildìti, èku satricināja jeb sagrāva zemestrīce (deinde operis parte effecta terrae motu concussum erat aedificium). [..] ja dabas spēku, [piemēram], zemestrīces, [ietekmē] tas atgadīies (si vi naturali, veluti terrae motu hoc acciderit), Flakam [pasūtītājam jeb izīrētājam] ir [jāuzṇemas] risks (Flacci esse periculum)." (D 19.2.59) [4, 290] 
Allars Apsītis, Dace Tarasova. Nomas jeb īres līguma piemērošana darba tiesisko attiecību reglamentēšanai jeb romiešu darbu īres līgums un romiešu darbuzṇēmuma līgums

Tāpat pasūtītājs jeb izīrētājs (locator) uzṇēmās bojāejas risku, ja viṇa vainas dēḷ tika kavēta darbu pien̦emšana vai viṇš izvairījās no darbu pien,emšanas:

“[..] jācieš pasūtitājam jeb izīrētājam ([..] nociturum locatori), ja viṇa kavēšanās dēl vai kā citādi darbi [nav] pieṇemti vai nomērīti (si per eum steterit, quo minus opus adprobetur vel admetiatur)." (D 19.2.36) [4, 289]

Savukārt, ja negadijums bija noticis nevis nepārvaramas varas (vis maior) ietekmē, bet gan nekvalitatīvi izpildìtu darbu, nepareizi pielietotu tehnologiju vai citu līdzīgu iemeslu dēḷ, zaudējumu ciešana piekrita uzñēmējam jeb īrniekam:

"Ja kanāls, kura izrakšanu [tu] īrē un paveic (si rivum, quem faciendum conduxeras et feceras) (t.i., uzñemies izrakt kanālu un darbu padari - autoru piez.), pirms tas pieñemts (antequam eum probares), zemes nogruvumā sabojāts (labes corrumpit) (t.i., aizbrucis - autoru piez.), [tas] ir tavs risks (tuum periculum est) [..] patiešām, ja grunts defekts [pie vainas], ka tas noticis (immo si soli vitio id accidit), pasūtitājam / izīrētājam būs risks [jāuzṇemas] (locatoris erit periculum); ja darbu defekta [dēl tas] noticis (si operis vitio accidit), tavs būs zaudējums (tuum erit detrimentum)." (D 19.2.62) $[4,291]$

\section{Līdzīgs gadījums:}

"Ja dārgakmens [meistaram] ietvarā iestrādāšanai vai iegravēšanai ir dots un ir saplaisājis (si gemma includenda aut insculpenda data sit eaque fracta sit), ja patiešām [tas dēḷ] defektīva materiāla saplaisājis ir (si quidem vitio materiae fractum sit), nebūs [ceḷams] no nomas jeb īres līguma prasījums (non erit ex locato actio), bet, ja pieredzes trūkums

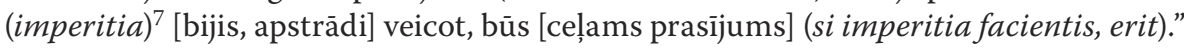
(D 19.2.13.5) [4, 285]

Kā jau iepriekš minēts, uzṇēmējs jeb īrnieks varēja labprātīgi uzṇemties papildu atbildību arī par nepārvaramas varas gadījumiem:

"[Bet ja] šis teikums [līgumam] ir pievienots (huic sententiae addendum est), ["] ja vien nav risku arī amatnieks uzṇēmies ["] (nisi periculum quoque in se artifex receperat), jo tad, kaut arī defektīva materiāla dēḷ tas noticis (tunc enim etsi vitio materiae id evenit), būs [pret vinu ceḷams] prasījums no nomas jeb īres līguma (erit ex locato actio)." (D 19.2.13.5) [4, 285]

Kopumā uz uzṇēmēja jeb īrnieka pienākumiem un atbildību darbojās princips, ka uzṇēmējam jeb īrniekam nav nepieciešams neko vairāk nodrošināt pasūtītājam jeb izīrētājam (non enim amplius praestari locatori oporteat) kā vien paša (uzṇēmēja jeb īrnieka) rūpību un [lai] darbi tiktu iegūti (quam quod sua cura atque opera consecutus esset) (D 19.2.36) [4, 289].

7 Imperitia - pieredzes jeb profesionālo iemaṇu, spēju, zināšanu trūkums, kas radīja atbildību personai, kura ar darbuzṇēmuma līgumu (locatio conductio operis) uzṇēmās pienākumu sniegt noteiktus profesionālus pakalpojumus, kaut arī tai trūka nepieciešamo zināšanu. Pieredzes trūkums tika uzskatits par vainas (culpa) formu (culpae adnumeratur) [2, 493]. 
Allars Apsītis, Dace Tarasova. Nomas jeb īres līguma piemērošana darba tiesisko attiecību reglamentēšanai jeb romiešu darbu īres līgums un romiešu darbuzṇēmuma līgums

Jāpiebilst, ka saistībā ar nomas jeb īres līgumiem - iznomāšanu un nomāšanu (locatio conductio) - pastāvēja vispārējs nosacījums, ka iespējama atbildības prasīšana par izmantoto viltu jeb tǐšu kaitējumu (dolus) un paaugstinātas rūpības trūkumu - respektīvi, pastāvēja paaugstināta atbildība par uzticētās lietas saglabāšanu (custodia), kas nozīmēja atbildēšanu arī par rupju un vieglu neuzmanību (culpa) un nejaušiem negadījumiem (casus), piemēram, uzticētās lietas nozagšanu, nodarbinātā personāla rīcību.

Kā jau iepriekš minēts, ja puses nebija citādi vienojušās, atbildības limits neietvēra nepārvaramas varas gadījumus, kam pretoties nav mūsu varā (casum, cui resisti non potest) (C 4.65.28) [3, 190]. Tā, piemēram, ja vēlējs / balinātājs bija pieṇēmis drēbes spodrināšanai un peles tās bija sagrauzušas (si fullo vestimenta polienda acceperit eaque mures roserint), viṇam bija saistošs prasijums no nomas jeb ìres līguma (ex locato tenetur), "[..] tāpēc, ka viṇam vajadzēja no šì patiešām piesargāties (quia debuit ab hac re cavere)".

Tāpat arī,

"[..] ja apmetni vēēejs / balinātājs apmaina un svešu [apmetni] citam atdod ([..] si pallium fullo permutaverit et alii alterius dederit), no nomas jeb ìres līguma prasijums saista, kaut [gan vinšs to] [būtu] darīijis neapzinoties (ex locato actione tenebitur, etiamsi ignarus fecerit)." (D 19.2.13.6) [4, 285]

Tādējādi uzṇemto saistību nepildīšanas gadījumā pret vainojamo uzṇēmēju jeb īrnieku varēja vērsties tiesā ar atbilstīgu prasījumu:

"Ja tie, kuri tevis īrēti (t.i., nodarbināti kā uzṇēmēji - autoru piez.) kviešu un miežu, [kas paredzēti] publiskajām izdalīšanām, piegādāšanai (si hi, qui a vobis redemerant frumentum et hordeum annonae inferendum), pien̦ēmuši naudu, uzticību piekrāpuši (accepta pecunia fidem fefellerunt), no nomas jeb ìres ligguma prasijumu celt pret tiem vari (ex locato agere cum his potestis)." (C 4.65.14) [3, 189]

\section{Lìdzīgs gadỉjums:}

"Izīrēju darbu izdarīšanai atbilstīgi (locavi opus faciendum ita), [..] darbs ir aplami paveikts (opus vitiosum factum est), vai varu celt prasijumu no nomas jeb ìres lìguma (an ex locato agere posisim)? Jurists Iavolenus atbildējis (respondit): ja tā darbs izīrēts (si ita opus locasti), ka vinna [izpildes] labas kvalitātes [apsolijums] tev no uzṇēmēja jeb îrnieka pieškirts (ut bonitas eius tibi a conductore adprobaretur), [..] nodrošinātas tomēr tev būtu [tiesības prasīt atbildību] no uznēēēja jeb îrnieka (praestari tamen tibi a conductore debet), ja tas darbs ir aplami paveikts (si id opus vitiosum factum est) [..]. Var tāpēc prasijumu no nomas jeb īres līguma celt pret viṇu (poterit itaque ex locato cum eo agi), kurš aplami darbu paveicis (qui vitiosum opus fecerit)." (D 19.2.51.1) $[4,289]$

Prasīājam labvēlīga sprieduma gadījumā bija iespējams atgūt pamatparādu kopā ar procentiem - tā, piemēram, avotos rodama norāde, ka pret tiem, kuri tiesības būvēt èkas noīrējuši, atbilstīgai tiesvedībai paredzēts prasījums no īres līguma, t.i., labticīgs prasījums, tādējādi parādu ar procentiem parasti atgūstot (adversus eos, a quibus extruenda aedificia conduxisti, ex conducto actione consistens eo iudicio quod est bonae fidei debitum cum usuris solitis consequeris) (C 4.65.2) [3, 189]. 
Allars Apsītis, Dace Tarasova. Nomas jeb īres līguma piemērošana darba tiesisko attiecību reglamentēšanai jeb romiešu darbu īres līgums un romiešu darbuzñēmuma līgums

Ja uzṇēmējam jeb îrniekam uzticētā lieta bija zaudēta kādas trešās personas rīcības (piemēram, zādzības) dēḷ un uzṇēmējs jeb îrnieks kompensēja pasūtītājam jeb izīrētājam tā zudušās lietas vērtìbu, pēdējam piekrita pienākums nodot jeb cedēt uzñēmējam jeb îrniekam savas tiesības vērsties pret minēto trešo personu - tiesības, kas viṇam kā lietas ipašniekam pienācās:

"Ja vēlējs / balināāājs vai labotājs / drēbnieks drēbes pazaudētu un tāpēc saimnieka [pretenziju] apmierinātu (si fullo aut sarcinator vestimenta perdiderit eoque nomine domino satisfecerit), ir nepieciešams, [lai] saimnieks savas prasijuma tiesības jeb vindikācijas un atprasijumus / atprasī̌sanas tiesības / kondikcijas [par labu amatniekam] cedētu / [uz amatnieku] pārvestu (necesse est domino vindicationem eorum et condictionem cedere)." (D 19.2.25.8) [4, 287]

Ja pasūtītājam jeb izīrētājam bija iespēja celt prasījumu pret zagli, kas viṇam piederošo un uzṇēmējam jeb îrniekam uzticēto lietu nozadzis, bet pasūtītājs jeb izīrētājs kaut kādu apsvērumu dēl izvēlējās prasījumu pret zagli necelt, viña prasījuma tiesības pret uzṇēmēju jeb ìrnieku vienalga saglabājās:

"Drēbes tavas vēlējs / balinātājs pazaudējis, un tev ir, no kurienes, [bet] nav vēlmes pieprasit tās atdot atpakal (vestimenta tua fullo perdidit et habes unde petas nec repetere vis), no nomas jeb īres līguma [tavas tiesības] prasīt nemazinās [strīdā] ar vēlēju / balinātāju (agis nihilo minus ex locato cum fullone)."

Tomēr šādā gadījumā tiesnesim bija pienākums izvērtēt (sed iudicem aestimaturum), vai šeit var pret zagli vairāk prasìt un no viņa lietas atgūt, vēlējam / balinātājam sedzot izmaksas ([..] adversus furem magis agere et ab eo [..] res consequi fullonis videlicet sumptibus),

"[..] bet ja tas [..] neiespējams būtu vinạa [kā tiesneša] ieskatā (sed si hoc [..] impossibile esse perspexerit), tad [tiesnesim] vēlējs / balinātājs patiešām tev [kā pasūtītājam jeb izīrētājam par labu] jānotiesā (tunc fullonem quidem tibi condemnabit), tomēr tavas prasijuma tiesības tev viṇam [kā uzṇēmējam jeb ìrniekam] nodot liekot (tuas autem actiones te ei praestare compellet)." (D 19.2.60.2) [4,290]

Par darbuzn̄ēmumu (locatio conductio operis) uzskatīja arī līgumu par preču vai pasažieru transportēšanu (pārvadājumu) (sk. (D 19.2.11.3) [4, 285], (D 19.2.25.7) [4, 287], (D 19.2.60.8) $[4,291])$.

Uzṇēmējs jeb îrnieks-transportētājs atbildēja par transportējamās kravas bojājumiem neatkarīgi no tā, vai tos nodarījis viṇš vai viṇa piesaistîts personāls. Avotos apskatìta situācija, kad kāds uzṇēmies būvkonstrukcijas (kolonnas) transportēšanu:

"Kurš kolonnas transportēšanu īrē (qui columnam transportandam conduxit), ja tā, noṇemot, pārvietojot vai atpakaḷ atliekot (dum tollitur aut portatur aut reponitur), ir saplaisājusi (fracta sit), lai [tad pats arī] risku (periculum) / atbildību uzn,emas, ja [tas] vai nu vin,a paša (qua ipsius eorumque), [vai to,] kuru darbi izmantoti (quorum opera uteretur), vainas (culpa) [dēl] noticis (acciderit)..." (D 19.2.25.7) [4, 287]

Tādi paši secinājumi bija izdarāmi, ja kāds īrē mucu vai balı̣u transportēšanu (si dolia vel tignum transportandum aliquis conduxerit), vai citu pārvietojamu lietu (res transferri potest) transportēšanu (D 19.2.25.7) [4, 287]. 
Allars Apsītis, Dace Tarasova. Nomas jeb īres līguma piemērošana darba tiesisko attiecību reglamentēšanai jeb romiešu darbu īres līgums un romiešu darbuzñēmuma līgums

Ja uzṇēmējs jeb īrnieks varēja pierādìt, ka veicis visus nepieciešamos rūpības un piesardzības pasākumus, kādus būtu veicis piesardzīgs un uzmanīgs cilvēks, vin,š bija jāatbrīvo no atbildības:

"Vaina tomēr nepastāv (culpa autem abest), ja ir visi fakti (si omnia facta sunt), ka ikviens bijis lıti rūpīgs [un] piesardzīgs (quae diligentissimus quisque observaturus fuisset)..."

(D 19.2.25.7) [4, 287]

Uzṇēmējs jeb īrnieks-transportētājs atbildēja par transportējamās kravas saglabāšanu un arī par aizsardzību pret trešo personu prettiesiskiem tīkojumiem. Avotos minēta situācija, kad kāds uzñēmējs jeb īrnieks uznēèmies transportēt vīnu no Kampānijas (vinum de Campania transportandum conduxisset). Vīna trauki, tos noliktavā novietojot, kḷūdaini tika apzīmogoti ar viņa un kāda cita (trešās personas) zīmogiem (signatum suo et alterius sigillo). Kaut gan bija strīdus (controversia) situācija ar trešo personu, transportētājam ar prasijumu no nomas līguma bija uzlikts pienākums (ex locato tenetur) nodrošināt, lai vīns bez strīdus tiktu atgriezts (vini sine controversia reddat) pasūtîtāja jeb izīrētāja valdỉjumā (ut locatori possessionem) (D 19.2.11.3) [4, 285].

Nevis pasūtītājam jeb izīrētājam, bet gan uzṇēmējam jeb īrniekam-transportētājam bija pienākums veikt iespējamo ceḷa nodokḷu jeb nodevu samaksu:

“[..] kad, tiltu šḳērsojot (id cum pontem transiret), [tilta] uzraugs sava tilta [šḳērsošanas] nodevu no viṇa pieprasīja (redemptor eius pontis portorium ab eo exigebat), [..] mūḷu dzinējam [pašam nodevu] pienākas samaksāt (mulionem praestare debere)."

(D 19.2.60.8) $[4,291]$

Izmantojot prasījumu no nomas jeb īres līguma (ex locato actionem), no uznēēēja jeb īrnieka-transportētāja varēja pieprasìt atlīdzinājumu par kravas sabojāšanu ceḷu satiksmes negadījumā:

"Vēl jautājums (item quaeritur), ja važonis (si cisiarius), t.i., kučieris (id est carucharius) brīdī, [kad] citus apdzìt cenšas (transire contendit), ratus apgāž (cisium evertit) un [transportēto] vergu savaino vai nogalina (et servum quassavit vel occidit). Domāju, no nomas jeb ïres [lïguma izriet, ka] ir pret vinu prasijums (puto ex locato esse in eum actionem) [cel̦ams], jo [viṇam] būtu jābūt savaldīgākam (temperare enim debuit) [..]." (D 19.2.13. pr.) [4, 285]

Par darbuzṇēmumu (locatio conductio operis) uzskatīja uzñēmēja jeb īrnieka veiktus būvdarbus uz pasūtītāja jeb izīrētāja zemes (sk. (D 19.2.22.2) [4, 287], (D 19.2.30.3) [4, 288], (D 19.2.59) [4, 290], (D 19.2.60.3) [4, 290], (C 4.65.2) [3, 189] u. c.) neatkarīgi no tā, kurš piegādājis materiālus - uzṇēmējs jeb īrnieks vai kāda trešā persona -, pasūtìtājs jeb izīrētājs bija zemes īpašnieks (D 19.2.22.2) [4, 287]:

"Kad salas apbūvēšana izīrēta (cum insulam aedificandam loco), lai uzṇēmējs / būvnieks / "ïrnieks" uz sava rēḳina visu dara (ut sua impensa conductor omnia faciat), [viņš] patiešām savu īpašumu (respektīvi, izmantotos būvmateriālus utt. - autoru piez.) man nodod (proprietatem quidem eorum ad me transfert), un tomēr [tā] ir noma jeb īre (et tamen locatio est), [jo šeit] izīrē, lai meistars iegūtu [tiesības veikt] savu darbu (locat enim artifex operam suam), t.i., [darba] darīšanas vajadzību (id est faciendi necessitatem)."

(D 19.2.22.2) [4, 287] 
Allars Apsītis, Dace Tarasova. Nomas jeb īres līguma piemērošana darba tiesisko attiecību reglamentēšanai jeb romiešu darbu īres līgums un romiešu darbuzñēmuma līgums

Tādējādi meistaram kā īrniekam tika izīrētas tiesības izpildìt celtniecības darbus. Avotos rodams kaut kas līdzīgs būvuzṇēmēja jeb ìrnieka sastādìtai un pasūtītāja jeb izīrētāja apstiprinātai celtniecības darbu izmaksu tāmei, kā arī minēts par rīcību gadījumā, kad būvuzṇēmēja jeb īrnieka sākotnējie izmaksu aprēḳini izrādījušies nepamatoti samazināti:

"Uzdevu tev izvērtēt (mandavi tibi ut excuteres), par cik [lielu summu] vēlies būvēt villu (lauku saimniecību) (quanti villam aedificare velles). Paziṇoji man, [ka] divu simtu [apmēra] izmaksās iekḷausies (renuntiasti mihi ducentorum impensam excutere), par minēto algu darbi tev [tika] izīrēti (certa mercede opus tibi locavi). Vēlāk es uzzināju, [ka] nav iespējams mazāk kā par trijiem simtiem šai villai tapt (postea comperi non posse minoris trecentorum eam villam constare). Iedoti tomēr tev bija simts, no kuriem tikmēr daḷa [jau] iztērēta (data autem tibi erant centum, ex quibus cum partem impendisses), [tad es] aizliedzu tev darbus [tālāk] darīt (vetui te opus facere). Teicu: ja darbu darīšana turpināsies, pret tevi darbojas [prasījums] no nomas līguma (ex locato tecum agere) un atlikusī nauda man atgriežama (ut pecuniae mihi reliquum restituas)." (D 19.2.60.4) $[4,291]$

Tāpat apskatītas arī būvuzṇēmēja jeb ìrnieka tiesības atkāpties no sākotnēji paredzētā būvprojekta nosacījumiem, ja vien saṇemts attiecīgs pasūtītāja jeb izīrētāja rīkojums:

"Likums noteica (respektīivi, pušu vienošanās paredzēja - autoru piez.), [ka] mājas [būvdarbu] veikšana izīrēta bija tā (lege dicta domus facienda locata erat ita), ka pieṇemšana vai nepieṇemšana [no] pasūtītāja jeb izīrētāja vai viṇa mantinieka bija [vajadzīga] (ut probatio aut improbatio locatoris aut heredis eius esset), [bet] uzṇēmējs jeb īrnieks saskaṇā ar pasūtītāja jeb izīrētāja gribu dažas [lietas] darbos mainīja (redemptor ex voluntate locatoris quaedam in opere permutaverat). Atbildēju, [ka] darbi patiešām atbilstīgi likumā noteiktajam (atbilstīgi tam, kā paredzēja pušu sākotnējā vienošanās autoru piez.) nešḳiet izdarīti (respondi opus quidem ex lege dicta non videri factum), bet, tā kā saskaṇā ar pasūtītāja jeb izīrētāja gribu izmaiṇas bija [izdarītas] (sed quoniam ex voluntate locatoris permutatum esset), uzñēmēju jeb īrnieku vajadzētu attaisnot (redemptorem absolvi debere)." (D 19.2.60.3) [4, 290]

\section{Secinājumi}

Saskaṇā ar romiešu tiesību principiem juridiskās konstrukcijas brīvu personu (ne vergu) nodarbināšanai par atlīdzību, pusēm savstarpēji vienojoties, tika būvētas uz nomas jeb īres līguma (locatio conductio) tiesiskās bāzes (D 19.2.22.1, D 19.2.48. pr.). Tādējādi manuālo darbu veikšanas tiesiskajam nodrošinājumam tika izmantoti galvenokārt divi uz nomas jeb īres līguma (locatio conductio) bāzes veidoti līgumi: darbu īres līgums jeb darba līgums (locatio conductio operarum) un darbuznēemuma līgums (locatio conductio operis (faciendi)).

Darbu ires jeb darba ligums (locatio conductio operarum) bija citas personas darba jeb sniegto pakalpojumu īrēšana - darbinieks kā savu darbu (operae) izīrētājs (locator) sniedza pakalpojumus darba devējam kā īrniekam (conductor) (sk., piemēram, D 19.2.19.9, D 19.2.19.10) atbilstīgi tam, kā puses bija savstarpēji vienojušās. Darbiniekam pienācās 
Allars Apsittis, Dace Tarasova. Nomas jeb īres līguma piemērošana darba tiesisko attiecību reglamentēšanai jeb romiešu darbu īres līgums un romiešu darbuzñēmuma līgums

atbilstīga samaksa / darba alga (merces) (D 19.2.38. pr.). Tika praktizēta pakalpojumu izīrēšana uz noteiktu termiṇu (C 4. 65. 22). Līguma spēkā esamību nevarēja apstrīdēt neapmierinātības dēl par samaksas apjomu (D 19.2.23). Lìgums bija uzskatāms par spēkā neesošu, ja tā nosacỉjumi bija pretrunā ar labiem tikumiem (C 8.38.4, C 2.3.6, D 45.1.61, D 50.17.116 u. c.). Ja līgumā bija atrunāts darba izpildes termiņšs, bet darbs termiṇā netika izpildīts, īrniekam jeb darba devējam piekrita pienākums samaksāt izīrētājam jeb darbiniekam atbilstīgi termiñā padarìtajam (D 19.2.58.1). Ja pakalpojumi tika izīrēti diviem īrniekiem jeb darba devējiem, darbiniekam jeb darbu izīrētājam pienācās strādāt tā labā, kurš hronologiski pirmais bija noslēdzis ar viṇu līgumu (D 19.2.26). Darba devējam jeb īrniekam piekrita tiesības tiesas ceḷa pieprasìt no darbinieka jeb izīrētāja to pienākumu izpildi, kurus viņš bija uzñēmies (D 19.2.48. pr., C 4. 65. 22). Avotos rodamas normas, kas vērstas pret darba devēju jeb ìrnieku patvalı un vardarbïbu pret saviem darbiniekiem jeb darbu izīrētājiem (D 19.2.13.4).

Darbuzṇēmuma līgums (locatio conductio operis (faciendi)) bija līgums, saskaṇā ar kuru uzṇēmējs kā īrnieks (conductor, redemptor operis) uzṇēmās pienākumu veikt pakalpojumus vai darbus (opus) no izīrētāja jeb pasūtītāja piegādātā materiāla vai ar viṇa materiālu par savstarpēji norunātu samaksu (merces).

Avotos minēts, piemēram, par dārgakmeṇu apstrādi (D 19.2.13.5), drēbju tīrīšanas pakalpojumiem (D 19.2.13.6, sk. arī D 19.2.25.8, D 19.2.60.2, I 3.24.1), drēbnieka pakalpojumiem (I 3. 24.1, sk. arī D 19.2.25.8), aizgādnību pār lietām pret samaksu (D 19.2.40), zeltkaļa pakalpojumiem (I 3.24.4) un starpniecību kviešu un miežu iepirkšanā publiskām vajadzībām (C 4. 65.14).

Ja darba izgatavošanai izmantoja izgatavotājam piederošu materiālu, tas bija pārdevuma līgums (emtio), nevis darbuzṇēmuma līgums (I 3.24.4). Pušu atrunātie maksāšanas noteikumi varēja paredzēt vai nu maksāšanu par visu darbu kopumā, vai pa daḷām - atsevišḳi par katru paveicamā darba tehnologisko elementu (D 19.2.51.1). Līgumā atrunātā pakalpojuma cena varēja tikt attiecināta uz visu darbu apjomu kopumā vai arī sadalīta pa atsevišḳām pozịijām (D 19.2.51.1). Cenā varēja iekḷaut atsevišḳi izdalītas materiālu un darbaspēka izmaksas (D 19.2.30.3). Tika praktizēta gan gabaldarba samaksa (D 19.2.30.3), gan maksāšana par noliktiem laika intervāliem (D 19.2.51.1).

Lai iestātos samaksas veikšanas pienākums, kā nosacỉjumu parasti atrunāja pasūtītāja jeb izīrētāja vai kādas trešās personas dotu apstiprinājumu - darbu pien̦emšanu (D 19.2.24 pr., D 19.2.30.3, D 19.2.36, D 19.2.37, D 19.2.51.1, D 19.2.60.3).

Lìdz brīdim, kad pasūtītājs jeb izīrētājs pieṇēma darbus, tie atradās īrnieka jeb uzṇēmēja atbildībā, kurš uzṇēmās risku par paveiktā darba iespējamu bojāeju (D 19.2.36). Izṇēmums bija nepārvaramas varas (vis maior) gadījumi, kad, ja vien puses nebija citādi vienojušās (sk. D 19.2.13.5), cieta pasūtītājs jeb izīrētājs, nevis uzṇēmējs jeb īrnieks (D 19.2.37, D 19.2.36). Tādējādi uznēēmējs jeb îrnieks neatbildēja par bojājumiem un zaudējumiem, kas cēlušies dabas spēku (vi naturali) ietekmē, saglabājot tiesības uz samaksu par padarīto (D 19.2.59). Tāpat pasūtītājs jeb izīrētājs uzṇēmās bojāejas risku, ja viṇa vainas dēl bija kavēta pieṇemšana vai notikusi izvairǐšanās no darbu pien̦emšanas (D 19.2.36). 
Allars Apsittis, Dace Tarasova. Nomas jeb īres līguma piemērošana darba tiesisko attiecību reglamentēšanai jeb romiešu darbu īres līgums un romiešu darbuzṇēmuma līgums

Savukārt, ja negadījums bija noticis nevis nepārvaramas varas ietekmē, bet gan nekvalitatīvi izpildītu darbu, nepareizi pielietotu tehnologiju vai citu līdzīgu iemeslu dēl, zaudējumu ciešana piekrita uzñēmējam jeb īrniekam (D 19.2.62, D 19.2.13.5). Jāpiebilst, ka saistībā ar nomas jeb īres līgumiem (iznomāšanu un nomāšanu) (locatio conductio) funkcionēja vispārējs nosacījums, ka ir iespējama atbildības prasīšana par piel̦auto viltu jeb tîšu kaitējumu (dolus) un paaugstinātas rūpības trūkumu - respektīvi, pastāvēja paaugstināta atbildība par uzticētās lietas saglabāšanu (custodia), kas nozīmēja atbildỉbu arī par rupju un vieglu neuzmanību (culpa) un nejaušiem negadỉjumiem (casus) (piemēram, uzticētās lietas nozagšanu, nodarbinātā personāla rīcību). Ja puses nebija citādi vienojušās, atbildības limits neietvēra nepārvaramas varas gadījumus, kam pretoties nav mūsu varā (casum, cui resisti non potest) (C 4.65.28; D 19.2.13.6).

Uzṇemto saistību nepildīšanas gadījumā pret vainojamo uzṇēmēju jeb īrnieku varēja vērsties tiesā ar atbilstīgu prasijumu no nomas jeb ìres līguma (ex locato actione) (C 4.65.14, D 19.2.51.1). Prasītājam labvēlīga sprieduma gadỉjumā bija iespējams atgūt pamatparādu kopā ar procentiem (C 4.65.2).

Ja uzṇēmējam jeb îrniekam uzticētā lieta bija zaudēta kādas trešās personas rīcības (piemēram, zādzības) dēḷ un uzṇēmējs jeb îrnieks kompensēja pasūtìtājam jeb izīrētājam tā zudušās lietas vērtìbu, pēdējam piekrita pienākums nodot jeb cedēt uzṇēmējam jeb īrniekam savas tiesības vērsties pret minēto trešo personu - tiesības, kas viñam kā lietas īpašniekam pienācās (D 19.2.25.8). Ja pasūtītājam jeb izīrētājam bija iespēja celt prasỉjumu pret zagli, kas viṇam piederošo un uzṇēmējam jeb îrniekam uzticēto lietu nozadzis, bet pasūtìtājs jeb izīrētājs kādu apsvērumu dēḷ izvēlējās prasījumu pret zagli necelt, viṇa prasījuma tiesības pret uznēēmēju jeb īrnieku vienalga saglabājās (D 19.2.60.2).

Par darbuzṇēmuma līgumu (locatio conductio operis) uzskatìja arī līgumu par preču vai pasažieru transportēšanu / pārvadāšanu (sk. D 19.2.11.3, D 19.2.13 pr., D 19.2.25.7, D 19.2.60.8) un uzṇēmēja jeb îrnieka (conductor) veiktus būvdarbus uz pasūtītāja jeb izīrētāja (locator) zemes (sk. D 19.2.22.2, D 19.2.30.3, D 19.2.59, D 19.2.60.3, D 19.2.60.4, C 4.65.2 u.c.).

Iepriekšminēto līgumu - gan darbu īres jeb darba līguma (locatio conductio operarum), gan arī darbuzñēmuma līguma (locatio conductio operis (faciendi)) - tiesiskais regulējums atzīstams par savam laikam pietiekami efektīvu, visai detalizētu un komplicētu legālo aparātu pilsoṇu mantisko interešu aizsardzībai.

Pētījuma rezultāti prezentēti RSU Juridiskās fakultātes organizētajā starptautiskajā zinātniski praktiskajā konferencē "Tiesiskās sistēmas modernizācijas virzieni: reālais stāvoklis un näkotnes perspektìvas" (Rìgā 2017. gada 26. aprīlì). 
Allars Apsītis, Dace Tarasova. Nomas jeb īres līguma piemērošana darba tiesisko attiecību reglamentēšanai jeb romiešu darbu īres līgums un romiešu darbuzñēmuma līgums

\section{Adaptation of Lease / Hire Contract in Regulation of Employment Relationship, or Roman Contract of Employment and Roman Contract for Work}

\section{Abstract}

The article deals with the results of the research performed on the original sources of the Roman Law in reference to legal construction concerning free persons' (but not slaves) employment for a certain payment on mutual agreement, which were based on legal grounds of lease / hire contract (locatio conductio), particulary on the legal basis of the contract of employment (locatio conductio operarum) and contract for work (locatio conductio operis).

Contract of employment (locatio conductio operarum) was a hire of another person's labour / services, where the employee as a lessor (locator) of his labour provided his services (operae) to the employer as a lessee (conductor) according to mutual agreement. Employee / lessor was entitled to a certain and appropriate remuneration / salary (merces). Contract for work (locatio conductio operis (faciendi)) was an agreement according to which the contractor / employee as a lessee (conductor, redemptor operis) had obligations to fulfil services or certain work on or from material supplied by the Commissioning Party / employer / lessor (locator), who took the obligation to pay the wages (merces) agreed upon.

There is, inter alia, described and analysed legal regulation found in the sources of the Roman Law regarding the rights and obligations of the contracting parties, the duration of contracts, pricing and terms of payment, approval and acceptance of work, risks and liabilities, mechanisms for protecting infringed rights etc.

The legal regulation of the aforementioned contracts must be regarded as sufficiently detailed, complex and effective legal apparatus for protection of material interests of Roman citizens.

Keywords: Roman Law, contract of employment, contract for work.

\section{Literatūra}

1. Apsitis, A. The reimbursement for the medical treatment expenses within the framework of Roman Partnership Agreement (Societa). SHS WEB Conferences. 2014, (10), 1-6. Iegūts no: http://dx.doi.org/10.1051/shsconf/20141000003 [sk. 24.09.2017.].

2. Berger, A. Encyclopedic Dictionary of Roman Law. Philadelphia: The American Philosophical Society, (1953) 1991. 461, 493, 539.

3. Krueger, P. (Ed.) Corpus Iuris Civilis. Vol. 2: Codex Iustinianus. Berolini: Weidmannos, 1906. 93, 189, 190, 351, 479. Iegūts no: http://fama2.us.es/fde/ocr/2007/corpusIurisCivilisCodexIustinianus.pdf, 123, 219, 220, 381, 509. [sk. 24.09.2017]. 
Allars Apsittis, Dace Tarasova. Nomas jeb īres līguma piemērošana darba tiesisko attiecību reglamentēšanai jeb romiešu darbu īres līgums un romiešu darbuzṇēmuma līgums

4. Krueger, P., Mommsen, T. (Eds.) Iustiniani Digesta. No: Corpus Iuris Civilis. Vol. 1: Institutiones. Digesta. Berolini: Weidmannos, 1928. 285, 287, 288, 289, 290, 291, 774, 923. Iegūts no: http:// fama2.us.es/fde/ocr/2006/corpusIurisCivilisT1InstitutionesDigesta.pdf, 368, 370, 371, 372, 373, 374, 857, 1006 [sk. 24.09.2017.].

5. Krueger, P., Mommsen, T. Iustiniani Institutiones. No: Corpus Iuris Civilis. Vol. 1: Institutiones. Digesta. Berolini: Weidmannos, 1928, 40. Iegūts no: http://fama2.us.es/fde/ocr/2006/corpusIurisCivilisT1InstitutionesDigesta.pdf, 63 [sk. 24.09.2017.].

6. Tarasova, D. Darba tiesisko attiecību izbeigšanas problemātika Darba likuma 101. panta pirmās dal̦as 3. un 4. punkta gadījumos. Socrates: RSU Juridiskās fakultātes elektroniskais juridisko zinātnisko rakstu žurnāls. 2016, 3(6), 99-107. Iegūts no: https://www.rsu.lv/sites/default/files/ imce/Dokumenti/izdevumi/socrates_6_2017.pdf [sk. 24.09.2017.].

7. Darba likums. 20.06.2001. (pamatredakcija). Latvijas Vēstnesis, 105 (2492), 06.07.2001. Stājies spēkā 01.06.2002. Konsolidētā redakcijā. Iegūts no: https://likumi.lv/doc.php?id=26019 [sk. 24.09.2017.]. 